\title{
Deep investigation of the effects of open trade policies on economic growth in West Africa: The case of the ECOWAS region
}

Essotanam Mamba ( $\sim$ essotanam@gmail.com )

Universities of Kara \& Lomé https://orcid.org/0000-0003-4516-8459

Evlo Kodjo

University of Lomé

\section{Research Article}

Keywords: Economic growth, endogeneity problem, financial development, open trade policies, panel data

Posted Date: January 27th, 2022

DOI: https://doi.org/10.21203/rs.3.rs-1239712/v1

License: (c) (1) This work is licensed under a Creative Commons Attribution 4.0 International License.

Read Full License 
Deep investigation of the effects of open trade policies on economic growth in West Africa:

The case of the ECOWAS region

\begin{abstract}
This study investigates the effects of open trade policies-OTP on economic growth for the Economic Community of West African States during 1980-2017 by applying the method of fixed effect with instrumental variables. Unlike several studies, we move from the univariate to the multivariate regression to show how the coefficient of OTP reacts. The univariate regression supports the positive effect of OTP on growth. However, the multivariate regression indicates that OTP reduces significantly growth. Meanwhile, these findings are robust to various econometric techniques. Furthermore, the paper shows the complementarity relationship between OTP and financial development. The results have important policy implications.
\end{abstract}

Keywords: Economic growth, endogeneity problem, financial development, open trade policies, panel data.

JEL Classification codes: C23, C26, E51; F1, F4 


\section{Introduction}

The most discussed question in the literature of international economics is the link between open trade policies (OTP) and economic growth. Some researchers including, Choi, Kim, and Ma (2021), Mamba (2021), Ramírez-Rondán et al. (2020), Bataka (2019), He and Xu (2019), Keho (2017), as well as international institutions (World Bank-WB, International Monetary Fund-IMF) and policymakers are interested in the role of trade for growth. Theoretically, there is an ambiguity about the effect of OTP on economic growth. We distinguish two main types of models: innovation models and learning by doing models. The innovation models from Grossman and Helpman (1991) and Rivera-Batiz and Romer (1991b) have shown that trade liberalisation between developed and least developed countries, LDCs, can improve economic growth. However, the learning by doing models from Lucas (1988) and Young (1991) preconise trade restrictions for the LDC. Also, from the empirical perspective, Laval et al. (2016), Musila and Yiheyis (2015), Polat et al. (2015), Ulaşan (2015), Nath (2009) have shown evidence that the effect of trade on economic growth is inconclusive.

As indicated by Rodriguez and Rodrick (1999), measuring trade openness is a challenging task and most of the empirical studies based on cross-country growth comparison fail to provide a satisfactory openness measure. There are several definitions and measures of trade openness. According to Krueger (1978), trade liberalisation can be achieved by using liberal and/or nonliberal policies. For Harrison (1996), "the concept of openness, applied to trade policy, could be synonymous with the idea of neutrality". Following Subasat (2008), Eriṣ and Ulașan (2013), trade liberalization is defined as the removal of barriers to free trade, namely tariffs, quotas, and exchange controls. From the neo-liberal trade theory, trade liberalisation and export promotion are synonymous, and trade liberalisation necessarily results in trade openness.

However as indicated by Yanikkaya (2003), from the empirical perspective, due to the difficulty in measuring openness, many different measures are used to analyse the effects of trade 
openness on economic growth. An ideal measure of a country's openness would be an index that includes all the instruments of trade policy (such as tariff and non-tariff barriers) that distort international trade. Since trade policies and trade volume measured by the share of international trade in GDP are still assumed to be strongly linked, some authors such as Easterly and Levine (2003) use these terms interchangeably. However, the link between trade volume and growth could differ from the relationship between trade policies and growth. Also, the theoretical growth literature has given more attention to the link between trade policies and growth rather than the relationship between trade volume and growth. For Yanikkaya (2003), this is because there are several other very important structural factors (geographical factors, countries size, and income) that influence trade volume independently of changes in the trade policy.

In this study, as Mamba (2021) and Musila and Yiheyis (2015), we use two proxies of trade openness: trade orientation index, and trade ratio (ratio of exports plus imports to GDP). We estimate the effect of open trade policies on the real GDP per capita in the Economic Community of West African States (ECOWAS) region. We find ambiguous effects of trade on economic growth. The univariate regression highlights the significant positive effect of trade on growth while the multivariate analysis shows the opposite sign. In addition, the findings show that the effect of OTP on growth may depend on the level of financial development. The results of the paper have important policy implications since trade reforms are frequently addressed in policy prescription packages by the WB and the IMF. Since the failure of substitution import policy (industrialisation strategies) the international institutions recommend in the 1980s larger openness through export stimulation. From this perspective, several countries (for instance, ECOWAS countries) are encouraged by World Trade Organisation, WTO. Also, ECOWAS is a regional trade group that is formed on May 28, 1975, via the Treaty of Lagos. On January 1, 2015, the ECOWAS adopted the Common External Tariff (CET). 
This research is most closely related to the recent study conducted by Mamba (2021). The study developed by Mamba (2021) is mainly focused on the non-linear that interacts trade orientation index (residual index) and governance. Thus, this paper contributes to the debate on the effect of open trade policies on the economic growth of ECOWAS countries in two ways. First, we deeply analyse the direct effect of trade (both residual and trade ratio) on economic growth in the ECOWAS region. As pointed by Mamba and Balaki (2021), while the inclusion of a large vector of control variables might help with the precision of the regressions, it might be worthwhile to introduce them step-wise to show how the coefficient on the variable of interest reacts. This is because some controls are quite correlated with the variable of interest. We, therefore, move from the univariate regression to the multivariate analysis. This procedure is very important because it helps to verify whether the effect of trade on growth passes (or not) through some other variables (Frankel and Romer, 1999).

Second, we explore the financial development channel contrary to Mamba (2021) who investigates the governance channel. Additionally, the study conducted by Ehigiamusoe and Lean (2018) in West Africa is limited to the finance-growth nexus while Menyah et al. (2014), Gries et al. (2009) investigated the interconnection between trade, financial deepening and economic growth in Africa and Sub-Saharan Africa, respectively. Besides, D'Onofrio and Rousseau (2018) explore the case for 17 economies. Other studies include Ramírez-Rondán et al. (2020) and Chang et al. (2009) for a sample of 80(82) countries over 1970-2015(1960-2000), respectively. The findings remain inconclusive, especially Ramírez-Rondán et al. (2020) confirm these findings based on the sub-sample analysis. Focusing on ECOWAS states is therefore important for policy implication perspective.

This paper analyses the effects (direct and indirect) of open trade policy on economic growth for ECOWAS countries. Following the conventional view, we assume that trade openness increases economic growth. We also suppose that financial development acts as a 
complementary policy in promoting growth. According to Manova (2008), the recent literature suggests that trade openness promotes domestic financial development, all of which contribute to economic growth and potentially to poverty reduction. The literature provides some channels, including comparative advantage, political power channel, insurance channel, demand for new financial products, through which trade and financial development may interact (Kim et al., 2010a,b). Supported by several works that provide evidence of the importance of financial development in economic development, African States including those from the ECOWAS region, in the last decades, have embarked upon financial sector reforms aimed at raising the development and capacity of financial systems (Gries et al., 2009). So far, the past decade has seen wide-ranging financial market reforms in Africa, coupled with private sector-led innovations.

The rest of the paper is structured as follows: Section 2 presents a brief theoretical and empirical review. Section 3 describes the methodology, while empirical analysis is given in section 4 . Section 5 concludes this paper with implications of economic policies.

\section{Literature review}

\subsection{Theoretical effects of trade on growth}

There is a growing literature on the link between trade and growth. The endogenous growth models from Baldwin (1992), Grossman and Helpman (1991), Rivera-Batiz and Romer (1991a,b), Krugman (1990), Romer (1990) provide a theoretical framework. This literature provides several channels through which trade may affect economic growth. These channels can be highlighted through the examination of four effects including transmission of technology effect, allocation of resources effect, redundancy or duplication effect, integration effect or market size increasing. Among these different effects, only the communication and redundancy channels necessarily increase economic growth. In this vein, the transmission of technology 
effect literature suggests that international trade facilitates the transmission of technologies by providing opportunities for communicating with foreign counterparts. The redundancy effect literature suggests that in the absence of international trade, some ideas and technologies are duplicated in countries. Trade liberalisation avoids the duplication cost of research and development (R\&D).

But, the allocation of resources and integration effects are ambiguous. For instance, it is recognized that integration increases the size of the market accessible to producers. While integration increases the competition, it also increases the vulnerability of the country that participates in international trade. Thus a weak initial specialisation in a given sector with dynamic economies of scale can lead to the progressive exclusion of this sector. According to Grossman and Helpman (1993), Rivera-Batiz and Romer (1991), Young (1991), Lucas (1988), Krugman (1987), if it is an engine sector of growth, a country can lose opening up to trade.

Additionally, while some channels, such as financial development, may be relevant in the connection between trade and growth, this is not explicitly highlighted in the above literature. As shown by Mamba and Balaki (2021), Ramírez-Rondán et al. (2020), Manova (2008, 2013), Baltagi et al. (2009), Do and Levchenko (2007), Blackburn and Hung (1998) there is an interaction between trade and financial development. These studies reveal that a weak financial system can reduce growth by constraining general activities, efficient allocation, investment opportunities, all productions and therefore trade openness. Reciprocally, restrictive trade liberalization leads to a misallocation of financial resources, reduces production and trade, which in turn affects growth.

Gries et al. (2009) indicate that increased trade liberalisation may trigger demand for new financial products and therefore financial development. Economies that are specialized in the production of goods requiring external finance will see their financial system to be developed. The comparative advantage literature suggests that after trade opening, the financially intensive 
sector expands in one economy and disappears in the other. This change in production patterns, in turn, influences equilibrium financial development in the trading economies, all of which affect growth. Openness (both trade and financial) reduces the incentives of incumbent business enterprises of financial institutions to block financial development in order to reduce entry and competition. Also, the relative political power of incumbents may decline with trade as well. While open trade is associated with some risks (external shocks and international competition) a developed financial system provides more adequate insurance and risk diversification.

\subsection{Empirical review}

The relationship between trade policy and economic growth has been the subject of several empirical studies. Some proxies of trade openness are used in the empirical literature. As in the theoretical framework, the empirical effect of trade on economic growth is ambiguous. Early empirical studies find the positive effect of trade openness on economic growth (Frankel and Romer, 1999; Sachs and Warner, 1995; Ben-David, 1993; Edwards, 1993; Dollar, 1992). However, recently, for instance, Polat et al. (2015) investigate the effect of trade measured by the sum of imports and exports to GDP during 1970-2011 for South Africa. Using the BayerHanck combined cointegration approach, they find a negative significant effect of trade on economic growth. Hye and Lau (2015) use the Auto-regressive distributive lag (ARDL) approach to analyse the link between trade openness and economic growth in the case of India over the period 1971-2009. Hye and Lau (2015) find that trade openness decreases economic growth in the long run, but not in the short run.

Musila and Yiheyis (2015), investigate the effects of trade openness on the economic growth rate in Kenya during the period 1982-2009. Authors use two measures of trade openness: aggregate trade openness measured by the ratio of exports plus import to GDP and trade-policy induced openness measured by the residual of aggregate trade openness. Employing OLS econometric approach, they find that aggregate trade openness affects positively but not 
significantly economic growth while trade-policy induced openness influences negatively and significantly economic growth. However, using the ARDL approach on time series data from 1981-2013, Lawal et al. (2016) find that trade openness, measured by the ratio of exports plus import to GDP, reduces significantly economic growth (real GDP per capita) of Nigeria.

Keho (2017) explores the case of Côte d'Ivoire over the period 1965-2014 by applying the ARDL approach. The author shows that trade openness (the sum of export and import to GDP) increases significantly economic growth measured by real GDP per capita both in the short and long run. However, Alhakmi (2017) uses the error-correction model ECM for the case of Kuwait and finds that international trade (sum of export and import to GDP) reduces significantly real GDP per capita. Ma et al. (2019) investigate the effect of trade openness (sum of exports and imports to GDP) on China provinces' economic growth. They work on a balanced panel of 30 provinces during 2002-2008 by using panel OLS and two-stage least square (2SLS). Their results indicate that trade openness rises economic growth. Choi et al. (2021) examine the link between trade policies and growth in emerging countries. The findings reveal that trade openness and the removal of trade barriers would raise growth.

Finally, while the link between trade and growth is well developed, the empirical studies on the trade-financial development-growth nexus remain less developed. Few studies examine the link between trade and financial development while other studies explore the connection between trade and/or financial development and economic growth using different approaches. Kim et al. (2010a) investigate the dynamic effects of trade openness on domestic financial development by using a pool mean group approach for panel data for 88 countries over the 1960-2005 period. The findings show the existence of a long-run relationship between trade and financial development with a negative short-run relationship. Also, Kim et al. (2010b) assessing whether financial development (domestic) and trade are complements or substitutes, they obtain similar findings. Bekele and Aegu (2021) explore the effect of financial development on economic 
growth of 25 SSA countries over the period 2010-2017. Using the GMM approach, they find that financial development significantly increases growth. But, Say et al. (2021) find that financial structure has a neutral effect on growth while financial services significantly enhance growth in Ghana.

Gries et al. (2009) explore the relationship between trade, financial development and economic development for 16 SSA States. The findings seem to show the neutral effect of trade and financial development on growth. Menyah et al. (2014) investigate the relationship between trade, financial deepening and economic development for 21 African States. Using the panel approach to Granger causality, the findings seem to show the neutral effect of trade and financial development on growth. D'Onofrio and Rousseau (2018) explore a panel of 17 economies to assess whether financial development (broad money, M3) and trade openness reinforce each other and lead to economic growth over the period (1850-1929). Panels, and VARs and vector ECMs for individual economies suggest that financial development led both trade and growth, while trade largely respond to financial development.

\section{Data and material}

\subsection{Data}

We explore three data sources. The data collected from WDI concern the dependent variable measured by the real per capita GDP (GDPpc), trade (OTP1), fixed telephone lines (TEL); foreign direct investment (FDI), active population (Pop_15), domestic credit to the private sector by banks (DCR), life expectancy at birth (LIF), and inflation rate (INF). In addition, we use data on the ratio of trade (OTP1), initial GDPpc, population density (DEN), and land area (LA) from this database to build a trade orientation index measured by the residual (OTP2) of the trade equation. The second is World Governance Indicators (WGI) which provide us data 
on governance (GOV). The third source is CEPII. From this source, data on landlocked and distance that captures the cost of transport are collected to build a trade orientation index.

The sample covers fifteen (15) ECOWAS countries: Benin, Burkina-Faso, Cabo Verde, Cote d'Ivoire, Ghana, Gambia, Guinea, Guinea-Bissau, Liberia, Mali, Niger, Nigeria, Senegal, Sierra Leone, and Togo over the period 1980-2017. Based on the existing literature, we use 3-annual average data (Mamba, 2021). Then, by averaging annual data, we control the business cycle fluctuations in the calculation of trade policy as the residual. An unbalanced panel data is used. Figure 1 shows the evolution of the trade orientation index (residual).

\section{Figure 1 (here)}

\subsection{Model}

Following similar studies, we use the new endogenous growth theory-NEGT framework (Mankiw, Romer, \& Weil, 1992) to examine the effect of open trade policy (OTP) on economic growth. However, the NEGT starts with the neoclassical production function. As Solow (1956) we consider the Cobb-Douglas production function.

$Y_{t}=f(A, K, L)$

where $\mathrm{Y}_{\mathrm{t}}$ is the real gross domestic product (GDP), A technological progress (exogenous in the model of Solow), K capital stock, and L labor. Following Yanikkaya (2003), we use fixed telephone lines (TEL) as a proxy of capital stock, while active population (POP_15) is used as a proxy of labor by Fetahi-Vehapi et al. (2015). The basic model is extended by assuming that A can be determined by other factors such as trade openness.

$A=g(I O T P, X)$

IOTP represents indices of open trade policy (trade ratio and its residual), and $\mathrm{X}$ is a vector of control variables. Substituting Eq. (2) into Eq. (1) we obtain Eq. (3): 
$Y_{t}=f\left(I O T P, X, T E L, P O P \_15\right)$

Following the existing literature, the vector of control variables includes governance (GOV), foreign direct investment (FDI), domestic credit to the private sector by banks (DCR), life expectancy at birth (LIF), and inflation rate (INF). Applying the natural logarithm (L) to the Eq. (3), the final model is:

$L G D P p c_{i t}=\alpha_{1} \cdot$ OTP $_{i t}+\alpha_{2} \cdot G O V_{i t}+\alpha_{3} \cdot T E L_{i t}+\alpha_{4} \cdot F D I_{i t}+\alpha_{5} \cdot L P O P P_{-} 5_{i t}+$ $\alpha_{6} \cdot L D C R_{i t}+\alpha_{7} \cdot L L I F_{i t}+\alpha_{8} \cdot I N F_{i t}+v_{i}+\varepsilon_{i t}$

with, $\varepsilon_{i t}=\mu_{t}+e_{i t}$

where $v_{\mathrm{i}}$ is the unobserved country-specific fixed effect, $\mu_{\mathrm{t}}$ the unobserved time-specific fixed effect, and $\mathrm{e}_{\text {it }}$ is the error term.

GDPpc is the dependent variable measured by the real per capita GDP in constant dollars 2010. OTP denotes indices of open trade policies. We use two types of trade policy. The first measure of open trade policy (OTP1) refers to the trade ratio (sum of exports and imports in percentage of GDP). This variable is often used as a proxy of trade policy in several studies such as Dollar and Kraay (2003), Easterly and Levine (2003), Yanikkaya (2003). The second measure is the trade orientation index (OTP2). This index is often used only in the multivariate regression framework Mamba (2021), Musila and Yiheyis (2015), Combes and Saadi-Sedik (2006). From this perspective, trade measured by the sum of exports and imports in percentage of GDP is determined by trade policy as well as a set of structural factors such as GDPpc, population density, landlocked, land area, and distance. To avoid the multicollinearity problem in the economic growth equation, we use the initial real GDPpc in the trade equation. The estimated residuals can be used as a more reliable indicator for openness subject to only trade policy compared to simple actual trade ratio (Eriṣ and Ulașan 2013; Pritchett, 1996; Leamer, 1988). A 
large value of residual indicates that the country is more open to international trade once the country's structural factors are controlled.

GOV, denotes governance or institutions. Institutional quality influences positively economic growth (Acemoglu and Robison 2012). As Easterly and Levine (2003), institution quality is captured by a governance index through the average of the six Kaufmann, Kraay, and Mastruzzi (2011) measures of institutional development: voice and accountability, political stability and absence of terrorist violence, governmental effectiveness regulatory quality, rule of law, and control of corruption. Each measure varies between -2.5 (weakest institutions), and 2.5 (strongest institutions). TEL denotes fixed telephone lines per 100 people. Following Yanikkaya (2003), we use telephone lines as a proxy for the physical capital stock. It is expected to be positively correlated with economic growth. POP_15 indicates active population between the ages of 15 and 64. It could be also used as a proxy of human capital that influences GDP per capita. Fetahi-Vehapi et al. (2015) have used active population in their studies. The coefficient of this variable is ambiguous.

FDI represents foreign direct investment, net inflows (\% of GDP). Fetahi-Vehapi et al. (2015), Nath (2009) employed this variable. The expected relation is ambiguous (negative or positive). DCR is domestic credit to the private sector by banks as a share of GDP. Its effect on economic growth is also ambiguous. Following Hadj fraj et al. (2018), we use this variable to capture the effect of financial development. LEB means life expectancy at birth, total (years). As Yanikkaya (2003), life expectancy was included to capture the effect of human capital. Theoretically, economic growth increases with the level of human capital. INF denotes inflation, GDP deflator (annual \%). The relationship between inflation and economic growth is ambiguous. This variable is used in some studies (Hadj fraj et al. 2018) to control for macroeconomic instability. 


\subsection{Estimation technique}

We begin with the traditional estimation techniques such as fixed effects (FE) estimates or random effects (RE) estimates following the Hausman specification test. The literature suggests that these methods control for the heterogeneity present in panel data (Mamba \& Balaki, 2021). These techniques may be reliable for one measure of trade policy (residual of trade ratio) in this study. However, as a growing body of the panel data literature indicates that panel data equations are likely to exhibit substantial cross-sectional dependence (CSD) in the error term, these techniques may suffer from the CSD issue. To this end, as the number of periods (T) is inferior to the number of individuals (N) the Driscoll and Kraay (1998) method could be applied.

However, for our first measure of trade policy (trade ratio) these techniques do not control for the endogeneity issue. Thus, we employ instrumental variables (IV) with fixed effect (FE) approach that is a powerful econometric approach to address the endogeneity problem (Wooldridge, 2002) and the CSD issue (Mamba, 2021; De Hoyos and Sarafidis, 2006). Especially, the IV+FE approach developed by Schafer (2010) controls for the autocorrelation issue and may be applied with and without endogenous explanatory variables. The major issue with using this econometric approach is that it is difficult to find good instruments for trade ratio that are correlated with the exogenous variables, but are not correlated with the error term. According to Mamba (2021), Mamba and Balaki (2021), Yanikkaya (2003), the actual or lagged values of the regressors could be employed as instruments. In addition, following Frankel and Romer (1999), the constructed trade share also called "natural trade openness" could be used as IV (IV is the predicted values of trade ratio). Also, the literature suggests that terms of trade or exchange rate could be used as IV for trade. Finally, correlation, multicollinearity, unit-root, and autocorrelation tests are conducted to support the results obtained. 


\section{Empirical analysis}

\subsection{Descriptive statistics, preliminary tests, and graphical analysis}

As above-mentioned, we use 3-annual average and annual data for trade orientation indexTOPR, and trade volume-TOPV, respectively. Table A1 shows descriptive statistics for annual data over 1980-2017. For the correlation and multicollinearity tests, the results are presented in Table A2 by including trade orientation and trade ratio indices, respectively. Overall, these tests suggest that all observed variables could be included in economic growth equation since the means of variance inflation factors (MVIF) are inferior to 5 (Mamba and Balaki, 2021; Mamba et al., 2020). But, for unobserved specific country characteristics, the multicollinearity tests reject their inclusion in regression (MVIFU are superior to 5).

The Fisher test of unit-root from Maddala and $\mathrm{Wu}(1999)$ is conducted for unbalanced panel data. The results presented in Table A3 indicate that all variables are stationary at level. This indicates that these variables could be included in regression. Finally, Table A4 presents autocorrelation and Hausman specification tests. Wooldridge test for autocorrelation in panel data indicates the presence of autocorrelation. The Hausman test rejects strongly fixed effect model in favor of random effect model.

For graphical analysis, we use the cross-sectional data. Therefore, the data used in this paragraph are the averages per country. Figure 2 shows the relationship between the variables of interest. We find a positive link between trade ratio and GDPpc or financial development. However, there is a negative relationship between residual and GDPpc while the correlation between residual and financial development seems to be positive.

Figure 2 (here) 


\subsection{Econometric results and interpretations}

The literature suggests that, in spite of the importance of control variables for causal inference, in practice, analysts often overstate their role in regressions. However, controls generally have no structural interpretation themselves. This is because even valid controls are often correlated with other unobserved variables, which renders their marginal effects ambiguous from a causal inference perspective. Thus, analysts should ignore them entirely in the section of the interpretation of the findings (Mamba and Balaki, 2021; Hünermund and Beyers, 2020). This practice prevents papers from wrong causal conclusions based on endogenous controls and allows to streamline the discussion sections of empirical studies and saves on valuable journal space (Hünermund and Beyers, 2020). We, therefore, focus on the interpretation of the variable of interest.

\subsubsection{Direct effects of open trade policies on economic growth}

As mentioned in the introduction, we move from the univariate regression to the multivariate analysis. Two proxies of open trade policies (trade ratio and the residual of trade ratio) are used to examine the effect of OTP on economic growth. We start the discussion with trade ratio and traditional estimation techniques. Thus, based on the Hausman specification test, fixed effect (FE) and random effect (RE) models are alternatively explored (Table 1).

\section{Table 1 (here)}

Univariate regression (column 1) reveals that variations in trade ratio significantly increase economic growth. This finding confirms the theoretical prediction and the conventional view on the effect of trade on growth. However, this finding contrasts that of Mamba (2021). A possible explanation is the exclusion of the control variables or the non-consideration of the endogeneity issue. Thus, when we consider controls, the findings from Table 1 indicate that OTP is negatively and significantly correlated with economic growth (column 2). Contrary to 
the conventional view, our results are consistent with the findings of Polat et al. (2015), Hye and Lau (2015). One possible explanation of the ambiguous effects of trade on growth here is that some control variables could serve as channels through which trade affect growth. In addition, the same result is obtained when we take into account country-specific effects (column 3). But the negative effect is less pronounced with the inclusion of these effects. We must explain this difference by the inclusion of country-specific effects that creates the multicollinearity issue (Table A4). However, the coefficient of trade openness becomes insignificant when we include the time-specific effect (column 4) or both country and timespecific effects (Column 5). Again, the insignificant effect of trade on growth confirms that the effect of trade passes through some observed control variables and unobserved dummy variables.

Furthermore, the above findings may suffer from CSD and endogeneity issues. As developed in the estimation techniques section, we use the Driscoll and Kraay, DK, (1998) method to control for the CSD issue while the IV+FE is one way to address these problems. The findings are displayed in Table 2.

Table 2 (here)

The findings relating to the DK approach are displayed in columns 1-2 while the IV+FE estimation findings are presented in columns 3-4. The statistically insignificant Hansen $\mathrm{J}$ statistic for overidentifying restrictions for the IV estimates shows that our instruments, including excluded instruments, are valid (Columns 3-4). Also, the endogeneity test of trade volume rejects the null hypothesis that trade volume is exogenous. These findings remain robust to those from Table 1 .

The finding in column 2 is from Mamba (2021). However, there are some major differences when moving from traditional estimation techniques $(\mathrm{FE} / \mathrm{RE}$ or $\mathrm{DK}+\mathrm{FE})$ to the $\mathrm{IV}+\mathrm{FE}$ 
technique. In absolute magnitude, the coefficient on trade raises sharply. The finding suggests that analysing the relationship between trade and income using FE/RE or DK+FE understates rather than overstates the effect of trade. These findings are supported by the economic literature (Mamba, 2021; Mamba \& Balaki, 2021, Frankel \& Romer, 1999). Beyond this, the sign changes from positive to negative when moving from univariate regression to multivariate analysis. Thus, these findings confirm the ambiguous effect of OTP on growth.

The second step in this section is the use of the second measure of trade policy measured by the residual of trade ratio. The results presented in Table 3 are based on the Hausman test.

\section{Table 3 (here)}

In general, the results remain robust to those from Table 1. The sign changes from positive to negative when we move from the univariate regression to the multivariate analysis. But, for this proxy of OTP, the findings from Table 3 may suffer from the CSD issue. As previously noted, we use the Driscoll and Kraay, DK, (1998) and IV+FE methods to control for the CSD problem. We find similar findings. In sum, we conclude that the effect of trade passes through some observed control variables and/or unobserved dummy variables.

Table 4 (here)

\subsubsection{Interaction model}

In this section, we investigate the indirect effect of open trade policies (OTP) on economic growth through a multiplicative model. The interaction term is the product between OTP and financial development and these variables separately represent the constitutive terms. Table 5 reports the findings of the multiplicative model using trade ratio as a proxy of OTP.

Table 5 (here) 
The two first columns present the findings relating to the use of traditional estimation techniques (random effects and Driscoll and Kraay methods). These findings seem to be similar in terms of signs and significance. These findings indicate that the interaction term is positively but insignificantly correlated with economic growth. After controlling for the endogeneity issue the findings become significant. For the constitutive terms, as the impact of OTP on economic growth depends on the level of financial development, we cannot say that an increase in OTP should result in a rising in growth. Thus, the coefficient on OTP $(-2.091)$ only captures the marginal effect of OTP on growth when financial development is zero. Alternatively, the coefficient on financial development $(-2.698)$ only captures the marginal effect of financial development on growth when OTP is zero. The coefficient of the interaction term is significantly positive suggesting that the marginal effect of OTP on growth increases with the level of financial development ${ }^{1}$. This finding suggests that OTP acts as a complement for financial development in enhancing growth. Our results are consistent with the findings reported by Menyah et al. (2014) for the case of Zambia, Chang et al. (2009).

Table 6 displays the findings based on the use of an alternative measure of trade policy (residual of trade ratio) which is supposed to be exogenous. In line with the findings in Table 5, the traditional estimation techniques suggest that OTP and financial development evolve independently.

Focusing on the IV approach, we follow the procedure suggested by Bun and Harrison (2019) which resembles the use of the lagged instruments in time series or panel data to find relevant instruments. This procedure is applied when one constitutive term is endogenous regressor (labeled DCR in our case), which interacts with an exogenous regressor (residual labeled OTP2

\footnotetext{
${ }^{1}$ Based on the findings in column 3, Table 7, the marginal effect of open trade policy (OTP1) on growth (GDPpc) is:$$
\frac{\partial L G D P p c}{\partial O T P 1}=\hat{\alpha}_{1}+\hat{\alpha}_{9} \cdot L D C R=-2.091+0.723 \cdot L D C R
$$ 
in our case). To find relevant (valid) instruments one can use the cross products or the squares or higher order of the exogenous regressors. Legal origin, for example, is used as a relevant instrument for financial development (La Porta et al., 1997). But, as this variable is a dummy variable its powers do not provide additional identifying information. We, therefore, use the cross products as valid excluded instruments (Table 6). Again, we find the positive and significant coefficient of the interaction term ${ }^{2}$. This finding suggests that OTP acts as a complement for financial development in enhancing growth.

\section{Table 6 (here)}

\section{Conclusion and implications of economic policies}

A wide range of previous empirical studies has shown that trade liberalisation leads to higher economic growth. The paper examines the effects of open trade policies on economic growth for ECOWAS countries over the period 1980-2017. Specifically, it is to examine the direct effect of open trade policies on growth and assess whether the effect of open trade policies on growth depends on the level of financial development. We use two measures of trade: trade ratio and trade orientation generated as residuals from the trade equation. We use the instrumental variables with fixed effects $(\mathrm{IV}+\mathrm{FE})$ to control for the endogeneity issue and/or the correlation among individuals. While the introduction of controls might help with the precision of the regressions, we move from the univariate regression to the multivariate analysis to show how the coefficient of the variable of interest reacts.

The univariate regression supports the positive effect of trade policies on economic growth. But, in contrast to the conventional view on the growth effects of open trade policies, the results

\footnotetext{
${ }^{2}$ Based on the findings in column 3, Table 8, the marginal effect of open trade policy (OTP2) on growth (GDPpc) is:$$
\frac{\partial L G D P p c}{\partial O T P 2}=\hat{\alpha}_{1}+\hat{\alpha}_{9} \cdot L D C R=-1.372+0.429 \cdot L D C R \text {. }
$$ 
of the multivariate regression indicate that trade openness reduces significantly economic growth. These findings suggest that the previous conclusions based on two case variables or limited variables analysis may be limited, because they cannot assess whether beyond the direct effect, the effect of trade passes (or not) through some observed control variables and/or unobserved dummy variables. These ambiguous effects of trade suggest that some control variables could serve as channels through which trade affect growth. Besides, these findings seem to be robust to various econometric techniques. Finally, the multiplicative interactive model shows the complementarity relationship between open trade policies and financial development.

The above findings have important policy implications. Policy-makers within the ECOWAS region should continue to implement outward-looking strategies by increasing the competitiveness of the ECOWAS countries. Also, policymakers should alternatively prioritize the combination of open trade policies and the development of the financial system to ensure growth. Doing so help to increase the comparative advantage and the international competition of the ECOWAS countries and reduce their vulnerability.

Further studies could explore country case studies or sub-regional studies to consider the country-specific characteristics. Other studies may go beyond the direct effect to explore some channels including investment (both domestic and foreign), human capital, inflation. 


\section{References}

Alhakmi, S-S. 2017: The impact of trade openness on per capital in Kuwait. Asian Economic and Financial Review 7(5): 448-455.

Acemoglu, D., Robison, J-A. 2012: Why nations fail: The origins of power, prosperity, and poverty. New York, NY Crown Publishers.

Baldwin, R-E. 1992: Measurable dynamic gains from trade. Journal of Political Economy 100: $162-174$.

Baltagi, B.H. Demetriades, P.O., Law, S.H. 2009: Financial development and openness: Evidence from panel data. Journal of Development Economics 89(2): 285-296.

Bataka, H. 2019: De jure, de facto globalization and economic growth in Sub-Saharan Africa. Journal of Economic Integration 34(1): 133-158.

Bekele, D., \& Degu, A. 2021: The effect of financial sector development on economic growth of selected sub-Saharan Africa countries. International Journal of Finance \& Economics. doi:10.1002/ijfe.2566.

Ben-David, D. 1993: Equalizing exchange: trade liberalization and income convergence. The Quarterly Journal of Economics 108(3): 653-679

Blackburn, K., \& Hung, V. 1998: A theory of growth, financial development and trade. Economica 65(257): 107-124.

Bun, M., Harrison, T. 2019: OLS and IV estimation of regression models including endogenous interaction terms. Econometric Reviews 38(7): 814-82.

Chang, R., Kaltani, L., \& Loayza, N. V. 2009: Openness can be good for growth: The role of policy complementarities. Journal of Development Economics 90(1): 33-49. 
Choi, S., Kim, H., Ma, X. 2021: Trade policies and growth in emerging economies: policy experiments. Review of World Economics 157: 603-629.

Combes, J-L., Saadi-Sedik, T. 2006: How dose trade openness influence budget deficits in developing countries? IMF working paper, WP/06/3.

De Hoyos, R., \& Sarafidis, V. 2006: Testing for cross-sectional dependence in panel-data models. The Stata Journal 6(4): 482-496.

Do, Q.-T., Levchenko, A. 2007: Comparative advantage, demand for external finance, and financial development. Journal of Financial Economics 86: 796-834.

Dollar, D. 1992: Outward-oriented developing countries really do grow more rapidly: Evidence from 95 LDCs, 1976-1985. Economic Development and Cultural Change 40: 523-544.

Dollar, D., Kraay, A. 2003: Institutions, trade, and growth. Journal of Monetary Economics 50(1): 133-162.

D’Onofrio, A., Rousseau, P.L. 2018: Financial development, trade openness and growth in the first wave of globalization. Comparative Economic Studies 60: 105-114.

Easterly, W., Levine, R. 2003: Tropics, germs and crops: how endowments influence economic development. Journal of Monetary Economics 50 (1): 3-39.

Edwards, S. 1993: Openness, trade liberalisation, and growth in developing countries. The Journal of Economic Literature 31(3): 1358-1393.

Ehigiamusoe, K.U., Lean, H.H. 2018: Finance-growth nexus: New insights from west African region. Emerging Markets Finance and Trade 54(11): 2596-2613.

Eriș, M-N., Ulașan, B. 2013: Trade openness and economic growth: Bayesian model averaging estimate of cross-country growth regressions. Economic Modelling 33: 867-883. 
Gries, T., Kraft, M., Meierrieks, D. 2009: Linkages between financial deepening, trade openness, and economic development: causality evidence from Sub-Saharan Africa. World development 37(12) : 1849-1860.

Fetahi-Vehapi, M., Sadiku, L., Petkovski, M. 2015: Empirical analysis of the effects of trade openness on economic growth: An evidence for South East European countries. Porcedia Economics and Finance 19: 17-26.

Frankel, J-A., Romer, D. 1999: Does trade cause growth? American Economic Review 80: 379399.

Grossman, G-M., Helpman, E. 1991: Quality ladders in the theory of growth. Review of Economics Studies: 43-62.

Grossman, G-M., Helpman; E. 1993: Innovation and growth in the global economy. MIT Pres, Cambridge.

Hadj fraj, S., Hamdaoui, M., Maktouf, S. 2018: Governance and economic growth: The role of the exchange rate regime. International Economics 1-83.

Harrison, A. 1996: Openness and growth: A time-series, cross-country analysis for developing countries. Journal of Development Economics 48(2): 419-447.

He, Q., Xu, B. 2O19: Determinants of economic growth: A varying-coefficient path identification approach. Journal of Business Research 1-8.

Hünermund, P., Beyers, L. 2020: On the nuisance of control variables in regressionanalysis. arXiv preprint arXiv:2005.10314v3

Hye, Q-M-A., Lau, W-Y. 2015: Trade openness and economic growth: empirical evidence from India. Journal of Business Economics and Management 16(1): 188-205. 
Kaufmann, D., Kraay, A., \& Mastruzzi, M. 2011: The world governance indicators: Methodology and analytical issues. Hague Journal on the Rule of Law 3(2): 220-246.

Keho, Y. 2017: The impact of trade openness on economic growth: the case of Ivory Cote. Cogent Economics \& Finance 5: 1-14.

Kim, D., Lin, S., \& Suen, Y. 2010a: Dynamic effects of trade openness on financial development. Economic Modelling 27(1): 254-261.

Kim, D., Lin, S., Suen, Y. 2010b: Are financial development and trade openness complements or substitutes? Southern Economic Journal 76(3): 827-845.

Krueger, A-O. 1978: Liberalisation attempts and consequences. Ballinger, Cambridge.

Krugman, P. 1987: A model of innovation, technology transfer, and the World distribution of income. Journal of Political Economy 87(1): 253-266.

Krugman, P. 1990: Rethinking international trade. Cambridge, Massachusetts: MIT press.

Laval, A-I., Nwanji, T-I., Asaleye, A., Ahmed, V. 2016: Economic growth, financial development and trade openness in Nigeria: An application of ARDL bound testing approach. Cogent Economics and Finance 4: 1-15.

La Porta, R., Lopez-de-Silanes, F., Shleifer, A., \& Vishny, R. 1997: Legal determinants of external finance. Journal of Finance 52: 1131-1150.

Leamer, E. (1988). Measures of openness. In R. Baldwin (eds) Trade policy issues and empirical analysis. Chicago, University of Chicago Press 147-200.

Lucas, R-E. 1988: On the mechanics of economic development. Journal of Monetary Economics 22(1): 3-42. 
Ma, J., Shi, J., Luo, D., Che, Y. 2019: Effect of trade openness on regional economic growth in China: revisiting the discussion. Applied Economics Letters 1-5.

Maddala, G-S., Wu, S. 1999: A comparative study of unit root tests with panel data and a new simple test. Oxford Bulletin of Economics and Statistics 631-652.

Mamba, E., Gniniguè, M., \& Ali, E. 2020: Effect of foreign direct investment on structural transformation in West African Economic and Monetary Union (WAEMU) countries. $\begin{array}{lllll}\text { Cogent Economics } \quad \& \quad \text { Finance } & \text { 8(1): } \quad 1783910 .\end{array}$ doi.org/10.1080/23322039.2020.1783910.

Mamba E. 2021: Role of governance in open trade policies-growth nexus in ECOWAS countries: The use of extended IV approach in panel data. Journal of International Trade \& Economic Development 30(5): 661-684. DOI: 10.1080/09638199.2021.1889643.

Mamba, E., \& Balaki, A. 2021: Effects of trade policies on external trade performances of ECOWAS countries (1996-2017). Economics of Transition and Institutional Change. doi:10.1111/ecot.12303

Mankiw, N-G., Romer, D., Weil, D-N. 1992: A contribution to the empirics of economic growth. Quarterly Journal of Economics 107(2): 407-437.

Manova, K. 2008: Credit constraints, equity market liberalizations and international trade. Journal of International Economics 76(1): 33-47.

Manova, K. 2013: Credit constraints, heterogeneous firms, and international trade. Review of Economic Studies 80(2): 711-44.

Menyah, K., Nazlioglu, S., Wolde-Rufael, Y. (2014). Financial development, trade openness and economic growth in African countries: New insights from a panel causality approach. Economic Modelling 37: 386-394. 
Musila, J-W., Yiheyis, Z. 2015: The impact of trade openness on growth: The case of Kenya. Journal of Policy Modeling 37: 342-354.

Nath, H. 2009: Trade, foreign direct investment, and growth: Evidence from transition economies. Comparative Economic Studies 51: 20-50.

Polat, A., Shahbaz, M., Rehman, I-U., Satti, S-L. 2015: Revisiting linkages between financial development, trade openness and economic growth in South Africa: fresh evidence from combined cointegration test. Quality and Quantity 49: 785-803.

Pritchett, L. 1996: Measuring outward orientation: Can it be done? Journal of Development Economics 49(2): 307-335.

Ramírez-Rondán, N., Terrones, M., Vilchez, A. 2020: Does financial sector development affect the growth gains from trade openness? Review of World Economics 156: 475-515.

Riviera-Batiz, L-A., Romer, P-M, 1991a: International trade with endogenous technological change. European Economic Review 35(4): 971-1002.

Riviera-Batiz, L-A., Romer, P-M. 1991b: Economic integration and endogenous growth. Quarterly Journal of Economics 106(2): 531-555.

Rodriguez, F., Rodrik, D. (1999). Trade policy and economic growth a skeptic'a guide to the cross-national evidence. NBER Working paper, (7081).

Romer, P-M. 1990: Endogenous technological change. Journal of Political Economy 98(85).

Sachs, J., Warner, A. 1995: Economic reform and the process of global integration trade. Brookings papers on Economic Activity 1: 1-118. 
Say, J., Zhao, H., Wang, F., \& Agbenyegah, F. 2021: Sources of economic growth: Bankerteers or marketeers or both? An auto regressive distributed lag (ARDL) evidence from Ghana. International Journal of Finance \& Economics. doi:10.1002/ijfe.2546.

Schaffer, M. 2010: xtivreg2: Stata module to perform extended IV/2SLS, GMM and AC/HAC, LIML and k-class regression for panel data models. http://ideas.repec.org/c/boc/bocode/s456501.html.

Solow, R. 1956 A contribution to the theory of economic growth. The Quarterly Journal of Economics 70(1): 65-94

Subasat, T. 2008: Do liberal trade policies promote trade openness? International Review of Applied Economics 22(1): 37-41.

Ulaşan, B. 2015: Trade openness and growth: panel evidence. Applied Economics Letters 22: 163-167.

Wooldridge, J-M. 2002: Econometric analysis of cross section and panel data. Cambridge.

Yanikkaya, H. 2003: Trade openness and economic growth: A cross-country empirical investigation. Journal of Development Economics 72(1): 57-89.

Young, A. (1991). Learning by doing and the dynamic effects of international trade. Quarterly Journal of Economics 106(2): 369-405. 
Tables

Table 1 Direct effects of trade ratio (OTP1) on growth (traditional estimation techniques)

\begin{tabular}{|c|c|c|c|c|c|}
\hline LGDPpc & $\begin{array}{l}\mathrm{FE} \\
\text { (1) }\end{array}$ & $\begin{array}{l}\text { RE } \\
\text { (2) }\end{array}$ & $\begin{array}{l}\mathrm{RE} \\
\text { (3) }\end{array}$ & $\begin{array}{l}\mathrm{RE} \\
\text { (4) }\end{array}$ & $\begin{array}{l}\mathrm{RE} \\
(5)\end{array}$ \\
\hline LOTP1 & $\begin{array}{r}0.202 * * \\
(0.093) \\
\end{array}$ & $\begin{array}{l}-0.185^{*} \\
(0.102) \\
\end{array}$ & $\begin{array}{l}-0.171 * \\
(0.101)\end{array}$ & $\begin{array}{r}-0.163 \\
(0.123)\end{array}$ & $\begin{array}{l}-0.163 \\
(0.103)\end{array}$ \\
\hline $\begin{array}{l}\text { Controls included } \\
\text { Effects: }\end{array}$ & No & Yes & Yes & Yes & Yes \\
\hline Country & No & No & Yes & No & Yes \\
\hline Period & No & No & No & Yes & Yes \\
\hline Obs & 191 & 118 & 118 & 118 & 118 \\
\hline Countries & 15 & 15 & 15 & 15 & 15 \\
\hline F/Wald Chi2 & $4.700 * *$ & $28.500 * * *$ & & & \\
\hline $\mathrm{R}^{2}$ & 0.016 & 0.632 & 1.000 & 0.695 & 1.000 \\
\hline
\end{tabular}

${ }^{*} \mathrm{p}<0.1 ;{ }^{* *} \mathrm{p}<0.05 ;{ }^{* * *} \mathrm{p}<0.01$. Robust standard errors in parentheses. 
Table 2 Estimation results for trade ratio, OTP1, (instrumental variables method)

\begin{tabular}{|c|c|c|c|c|}
\hline LGDPpc & $\begin{array}{r}\mathrm{DK}+\mathrm{FE} \\
(1)\end{array}$ & $\begin{array}{r}\mathrm{DK}+\mathrm{FE} \\
(2)\end{array}$ & $\begin{array}{r}\mathrm{IV}+\mathrm{FE} \\
(3)\end{array}$ & $\begin{array}{r}\mathrm{IV}+\mathrm{FE} \\
(4)\end{array}$ \\
\hline LOTP1 & $\begin{array}{l}0.201 * * * \\
(0.057) \\
\end{array}$ & $\begin{array}{c}-0.171 * \\
(0.093)\end{array}$ & $\begin{array}{c}0.403 * * * \\
(0.096) \\
\end{array}$ & $\begin{array}{r}-0.714^{* * * *} \\
(0.231) \\
\end{array}$ \\
\hline Controls included & No & Yes & No & Yes \\
\hline Obs & 191 & 191 & 174 & 99 \\
\hline Countries & 15 & 15 & 15 & 15 \\
\hline $\mathrm{F}$ & $12.550 * * *$ & $30811.900 * * *$ & $17.560 * * *$ & $5.010 * * *$ \\
\hline $\mathrm{R}^{2}$ & 0.045 & 0.631 & 0.039 & 0.156 \\
\hline Hansen J statistic & & & 0.468 & 1.517 \\
\hline Endogeneity test & & & $7.405 * * *$ & $10.344 * * *$ \\
\hline \multicolumn{5}{|c|}{ First-stage regression } \\
\hline F_OTP1 & & & $46.500 * * *$ & $4.940 * * *$ \\
\hline
\end{tabular}

Notes: exchange rate and devaluation are used as valid excluded instruments ${ }^{*} \mathrm{p}<0.1 ; *{ }^{*} \mathrm{p}<0.05 ; * * * \mathrm{p}<0.01$. Robust standard errors in parentheses. 
$\underline{\text { Table } 3 \text { Direct effects of trade policy (residual) on growth (traditional estimation techniques) }}$

\begin{tabular}{lrrrrr}
\hline LGDPpc & \multicolumn{1}{c}{ FE $(1)$} & \multicolumn{1}{c}{ RE $(2)$} & \multicolumn{1}{c}{ RE (3) } & RE (4) & \multicolumn{1}{c}{ RE (5) } \\
\hline OTP2 & $0.209^{* *}$ & $-0.206^{* *}$ & $-0.209^{* *}$ & $-0.173^{*}$ & -0.164 \\
(Residuals) & $(0.086)$ & $(0.097)$ & $(0.100)$ & $(0.101$ & $(0.103)$ \\
\hline Controls & No & Yes & Yes & Yes & Yes \\
included & & & & & \\
Effects: & & & & & \\
Country & No & No & Yes & No & Yes \\
Period & No & No & No & Yes & Yes \\
\hline Obs & 191 & 118 & 118 & 118 & 118 \\
Countries & 15 & 15 & 15 & 15 & 15 \\
F/Wald Chi2 & $6.030^{* *}$ & $1043.690^{* * *}$ & $2439.790^{* * *}$ & &. \\
$\mathrm{R}^{2}$ & 0.051 & 0.676 & 0.751 & 1.000 & 1.000 \\
\hline
\end{tabular}

${ }^{*} \mathrm{p}<0.1 ; * * \mathrm{p}<0.05 ; * * * \mathrm{p}<0.01$. Robust standard errors in parentheses. 
Table 4 Robustness checks

\begin{tabular}{lrrrr}
\hline LGDPpc & $\mathrm{DK}+\mathrm{FE}$ & $\mathrm{DK}+\mathrm{FE}$ & $\mathrm{IV}+\mathrm{FE}$ & $\mathrm{IV}+\mathrm{FE}$ \\
& $(1)$ & $(2)$ & $(3)$ & $(4)$ \\
\hline OTP2 & $0.209^{* * *}$ & $-0.173 * * *$ & $0.209 * * *$ & $-0.173 * *$ \\
Residuals) & $(0.058)$ & $(0.094)$ & $(0.068)$ & $(0.079)$ \\
\hline Controls included & $\mathrm{No}$ & $\mathrm{Yes}$ & $\mathrm{No}$ & $\mathrm{Yes}$ \\
\hline Obs & 191 & 118 & 191 & 118 \\
Countries & 15 & 15 & 15 & 15 \\
$\mathrm{~F}$ & $13.250^{* * *}$ & & $9.370 * * *$ & $10.400^{* * *}$ \\
$\mathrm{R}^{2}$ & 0.051 & 0.8208 & 0.051 & 0.632 \\
\hline $\mathrm{p}^{2}<0.1 ; * * \mathrm{p}<0.05 ; * * * \mathrm{p}<0.01$. Robust standard errors in parentheses.
\end{tabular}


Table 5 Open trade policy (trade ratio as OTP1), financial development and growth

\begin{tabular}{lrrr}
\hline GDPpc & RE (1) & DK + FE (2) & IV+FE (3) \\
\hline LOTP1 & -0.390 & -0.261 & $-2.091^{* *}$ \\
LDCR & $(0.312)$ & $(0.217)$ & $(0.858)$ \\
& -0.266 & -0.099 & $-2.698^{* *}$ \\
LOTP1•LDCR & $(0.423)$ & $(0.247)$ & $(1.259)$ \\
& 0.084 & 0.036 & $0.723^{* *}$ \\
Obs & $(0.111)$ & $(0.069)$ & $(0.321)$ \\
Countries & 118 & 118 & 115 \\
F/Wald & 15 & 15 & 15 \\
R & $1467.280^{* * *}$ & $27904.420^{* * *}$ & $6.140^{* * *}$ \\
\hline Hansen J statistic & 0.637 & 0.632 & 0.039 \\
Endogeneity test of & & & 1.378 \\
endogenous regressors & & & $19.170^{* *}$ \\
First stage regression & & & $8.880^{* * *}$ \\
LOTP1 & & & $20.810^{* * *}$ \\
LDCR & & & $6.250^{* * *}$ \\
LOTP1_LDCR & & &
\end{tabular}

Notes: Terms of trade, 1-period lagged values of trade ratio and financial development and two year lagged value of their interaction are used as valid excluded instruments.

${ }^{*} \mathrm{p}<0.1 ; *{ }^{*} \mathrm{p}<0.05 ; * * \mathrm{*}<0.01$. Robust standard errors in parentheses. 
Table 6 Open trade policy (residual as OTP2), financial development and growth

\begin{tabular}{lrrr}
\hline GDPpc & RE (1) & DK +FE (2) & IV + FE (3) \\
\hline OTP2 & -0.317 & -0.206 & $-1.372^{* *}$ \\
& $(0.262)$ & $(0.169)$ & $(0.627)$ \\
LDCR & $0.081^{*}$ & 0.047 & $0.422^{* * *}$ \\
& $(0.043)$ & $(0.054)$ & $(0.114)$ \\
OTP2•LDCR & 0.045 & 0.013 & $0.429^{*}$ \\
& $(0.089)$ & $(0.046)$ & $(0.223)$ \\
\hline Obs & 118 & 118 & 118 \\
Countries & 15 & 15 & 15 \\
F/Wald & $1425.190^{* * *}$ & $57746.390^{* * *}$ & $5.850^{* * *}$ \\
$\mathrm{R}^{2}$ & 0.677 & 0.632 & 0.209 \\
\hline Hansen J statistic & & & 0.020 \\
Endogeneity test of & & & $15.106^{* * *}$ \\
endogenous regressors & & & $16.010^{* * *}$ \\
First stage regression & & & $4.270^{* * *}$ \\
LDCR & & & \\
LOTP2_LDCR & & & . \\
\hline
\end{tabular}

Notes: 1-period lagged values of financial development, products between trade policy (residual) and origin legal (French or English) or religion (Muslim) are used as valid excluded instruments.

${ }^{*} \mathrm{p}<0.1 ;{ }^{*} \mathrm{p}<0.05 ;{ }^{* *} \mathrm{p}<0.01$. Robust standard errors in parentheses. 


\section{Appendix}

Table A1 Descriptive statistics with annual data

\begin{tabular}{llllll}
\hline Variable & Observations & Mean & $\begin{array}{l}\text { Standard. } \\
\text { Deviation }\end{array}$ & Minimum & Maximum \\
\hline GDPpc & 564 & 825.7756 & 592.7584 & 115.7941 & 3536.957 \\
OTP1 & 551 & 66.69686 & 30.49471 & 6.320343 & 311.3553 \\
GOV & 285 & -0.5981929 & 0.5065137 & -1.807697 & 0.7248439 \\
TEL & 557 & 1.201038 & 2.545718 & 0 & 15.58545 \\
FDI & 550 & 4.175737 & 14.50616 & -82.8921 & 159.7189 \\
POP_15 & 570 & 8199361 & $1.63 \mathrm{e}+07$ & 136864 & $1.02 \mathrm{e}+08$ \\
DCR & 570 & 14.1618 & 11.60676 & 0 & 65.27793 \\
LIF & 555 & 52.99479 & 7.128332 & 35.705 & 72.798 \\
INF & 562 & 11.55716 & 20.81227 & -29.17246 & 165.6766 \\
\hline
\end{tabular}


Table A2 Correlation and multicollinearity tests including trade orientation index

\begin{tabular}{|c|c|c|c|c|c|c|c|c|c|}
\hline & OTP1 & OTP2 & GOV & TEL & FDI & LPOP_15 & LDCR & LIF & INF \\
\hline OTP1 & 1.000 & & & & & & & & \\
\hline OTP2 & 0.792 & 1.000 & & & & & & & \\
\hline GOV & 0.148 & 0.211 & 1.000 & & & & & & \\
\hline TEL & -0.030 & 0.354 & 0.617 & 1.000 & & & & & \\
\hline FDI & 0.179 & 0.322 & -0.068 & -0.007 & 1.000 & & & & \\
\hline LPOP_15 & 0.151 & 0.223 & -0.269 & -0.556 & -0.115 & 1.000 & & & \\
\hline LDCR & 0.357 & 0.446 & 0.574 & 0.514 & 0.054 & 0.075 & 1.000 & & \\
\hline LLIF & 0.332 & 0.501 & 0.634 & 0.602 & 0.138 & -0.356 & 0.636 & 1.000 & \\
\hline INF & 0.067 & -0.013 & -0.195 & -0.199 & -0.039 & 0.255 & -0.252 & -0.294 & 1.000 \\
\hline VIF_OTP1 & 1.440 & & 2.130 & 3.240 & 1.110 & 2.490 & 3.210 & 2.810 & 1.260 \\
\hline VIF_OTP2 & & 1.750 & 2.250 & 2.990 & 1.800 & 2.590 & 3.360 & 2.780 & 1.280 \\
\hline \multicolumn{10}{|c|}{ MVIF_OTP1 = 2.210} \\
\hline \multicolumn{10}{|c|}{ MVIFU_OTP1 $=38.430$} \\
\hline \multicolumn{10}{|c|}{ MVIF_OTP2 $=2.270$} \\
\hline MVIFU_OT & $2=38.4$ & & & & & & & & \\
\hline
\end{tabular}


Table A3 Unit-root tests

\begin{tabular}{lrrr}
\hline \multirow{2}{*}{ Variables } & \multicolumn{2}{c}{ Level (with OTP2) } & Decision \\
\cline { 2 - 3 } LGDPpc & Chi2 & Prob & $\mathrm{I}(0)$ \\
LOTP1 & 64.6372 & 0.0002 & $\mathrm{I}(0)$ \\
OTP2 & 54.1936 & 0.0044 & $\mathrm{I}(0)$ \\
GOV & 75.9432 & 0.0000 & $\mathrm{I}(0)$ \\
TEL & 76.4824 & 0.0000 & $\mathrm{I}(0)$ \\
FDI & 57.3964 & 0.0019 & $\mathrm{I}(0)$ \\
LPOP_15 & 84.6378 & 0.0000 & $\mathrm{I}(0)$ \\
LDCR & 55.3409 & 0.0032 & $\mathrm{I}(0)$ \\
LLIF & 67.5071 & 0.0001 & $\mathrm{I}(0)$ \\
INF & 51.2530 & 0.0092 & $\mathrm{I}(0)$ \\
\hline
\end{tabular}


Table A4 Autocorrelation and Hausman specification tests

\begin{tabular}{lcc}
\hline Tests & Model with LOTP1 & Model with OTP2 \\
\hline Autocorrelation test & & \\
$\mathrm{F}(1,14)$ & 44.099 & 44.200 \\
Prob $>$ F & 0.000 & 0.000 \\
\hline Hausman specification test & & \\
Chi2 $(8)$ & 9.530 & 9.240 \\
Prob $>$ chi2 & 0.299 & 0.322 \\
\hline
\end{tabular}


Figures

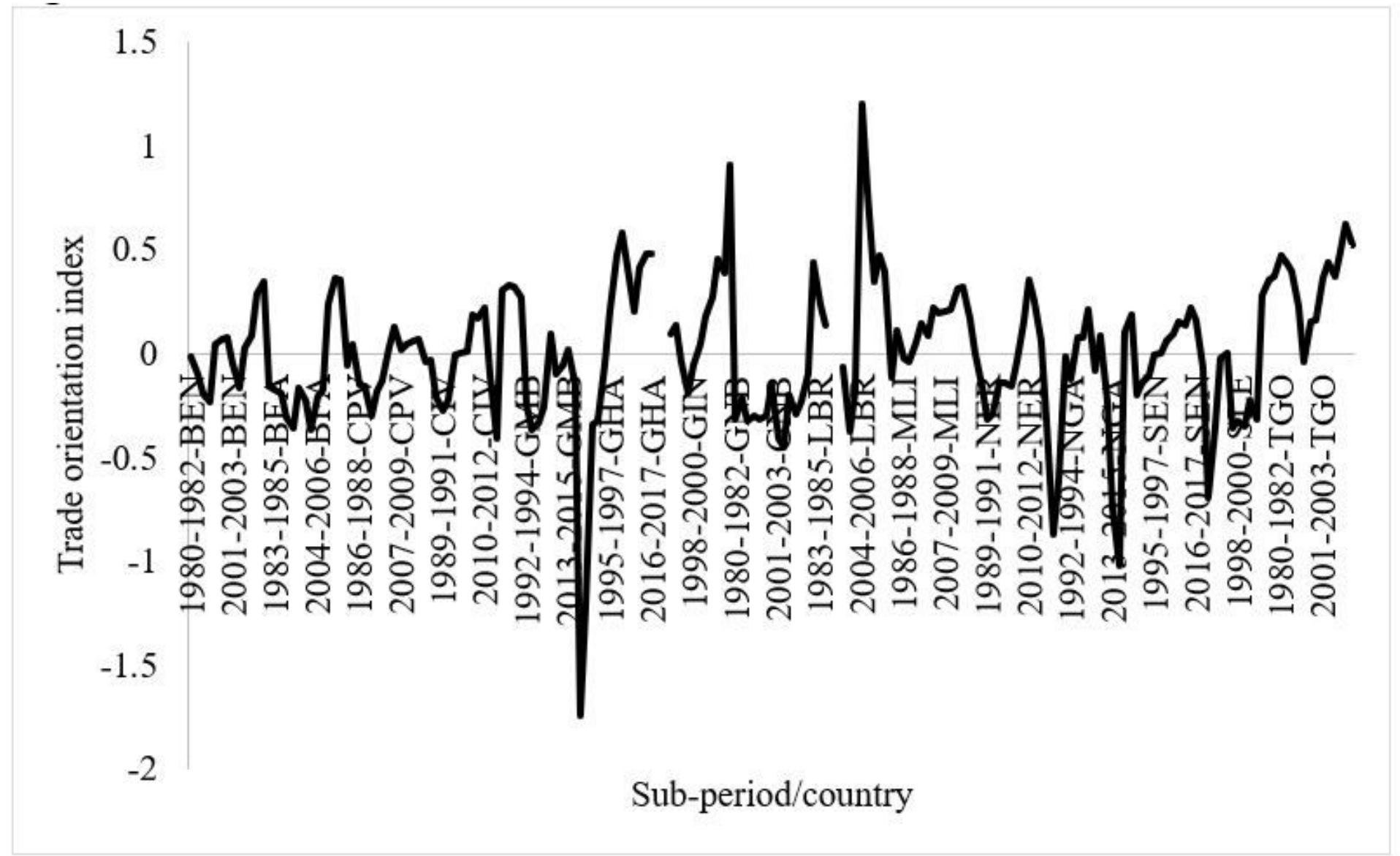

Figure 1

Evolution of trade orientation index in ECOWAS countries 

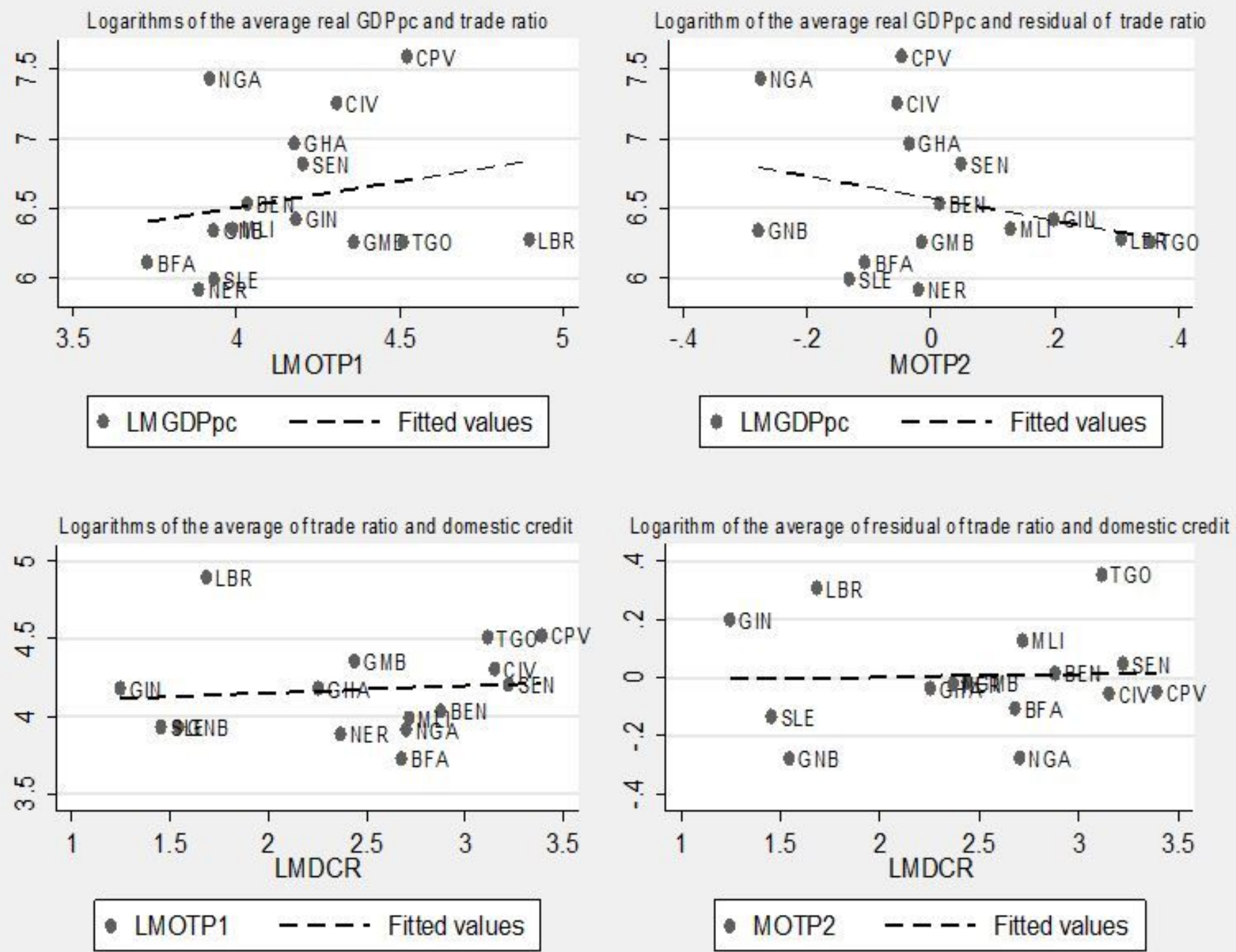

Notes: OTP1 and OTP2 denote trade ratio, and residual of trade ratio, respectively.

Figure 2

Correlation between the variables of interest 